\title{
FORMATION OF SELF-REGULATION CULTURE OF PHYSICAL EDUCATION FACULTY
}

\author{
Kudin S.F.
}

Chernigov National Pedagogical University

\begin{abstract}
Purpose: to experimentally substantiate effectiveness of pedagogic conditions of self-regulation culture formation of future physical culture teachers. Material: in the research $1103^{\text {rd }}$ year students of physical education faculty participated. The students were questioned. The level of students' anxiety was assessed. Results: Implementation of the author's course in educational process facilitated formation of students' self-regulation skills and abilities; raises confidence and self estimation; influences positively on functional state. It was found that students acquire ability to consciously observe their own verbal constructs of negative thinking and create positive alternatives. Conclusions: preparing of future physical culture teachers stipulates his (her) ability to effectively fulfill professional functioning in the aspect of health preservation. The necessary conditions of selfregulation culture formation are formation of students' holistic value-meaningful attitude to individual health and health of surrounding people.
\end{abstract}

Key words: physical culture, professional training, self-regulation, self-regulation culture.

\section{Introduction}

Protection and strengthening of children and youth's health are one of main tasks of social program in many countries. At present stage of Ukrainian society's development protection of young generation's health is still an acute question. Indicators and tendencies still remain unsatisfactory [15]. Realization of state policy of health protection also can not be considered excellent. It is proved by many scientific researches [13, 14, 18, and 20]. School shall create all conditions for health protection of its disciples. At the same time school also is rather specific risk factor in aspect of pupils' morbidity $[1,12]$. Constant physical, intellectual and emotional overloads, stress situations cause discomfort in pupils and teachers [9].

Health, by its essences, shall be the first demand of man. But satisfaction of this demand has complex, contradictory character. It results not always in desirable way that is conditioned by many circumstances. In particular, health culture, as system of health control yet has not taken important place in hierarchy of demands and values of pupils and students $[2,4,6,7,13,15,17,19,21-24]$.

Analysis of literature sources and the author's many years' experience in system of higher pedagogic education permits to speak about urgency of this problem. This problem is conditioned by contradiction between society's demand in physical culture teachers and insufficient level of scientifically substantiated approaches to formation of pupils', students' and teachers' self-regulation culture [3, 5, 8, and 11].

\section{Purpose, tasks of he work, material and methods}

The purpose of the work is to test experimentally effectiveness of pedagogic conditions of self-regulation culture formation of physical education faculty students.

The task of work is to test the author's training-methodic complex for students. The complex includes: working program, methodic recommendations on study of special course: Psycho-valueology", tasks for independent training, automated testing system "Camomile Net" for final control of knowledge [9, 10]. The logic of building of training work implies students' gradual mastering of the following: theoretical principles of human health and self-regulation; methodic of individual health assessment; practical skills of self-regulation, which can be used by future physical culture teachers in their professional functioning and everyday life. Important component of this course is worked out by the author methodic of studying of self-regulation theoretical principles and practical means of its application [10]. In formation of self-regulation skills special accent was made on teaching students to conscious observation of own verbal constructs of negative thinking and on techniques of positive alternatives' construction.

In the research $3^{\text {rd }}$ year 110 (82 boys and 28 girls) students of physical education faculty of Chernigov National Pedagogical University, named after T.G. Shevchenko, participated. In experiment we used observation methods, talks, questioning, and psycho-diagnostic testing of students' anxiety by methodic of anxiety's 
assessment of Spielberg Ch.D. and Khanin Yu.L.; experts' assessment and self assessment of emotional selffeeling by the worked out by the author scale

[9]; statistical methods. Confidentiality of results was assessed by Student's criterion.

Results of research

For determination of effectiveness of self-regulation culture formation's pedagogic conditions we questioned students of experimental group. Analysis of questioning results (see table 1) showed that students' awareness of modern self-regulation means is rather low (18.1\%). However, significant part of students would like to acquire knowledge in this field for stabilization of individual psycho-emotional state (47.1\%). Students consider it an important component of their professional qualities $(40.6 \%)$.

Table 1. Questioning results, \%

\begin{tabular}{|c|c|c|c|c|}
\hline \multirow[b]{2}{*}{ Questions } & \multicolumn{2}{|c|}{ Answers } & \multirow[b]{2}{*}{$\begin{array}{l}\text { Difficult } \\
\text { answer }\end{array}$} & \multirow[b]{2}{*}{ to } \\
\hline & Yes & No & & \\
\hline Do you know modern self-regulation means? & 18.1 & 28.2 & 53.7 & \\
\hline $\begin{array}{l}\text { Is it necessary to study in the courses of principles of medical } \\
\text { knowledge, valueology, psycho-valueology, psycho-physiology, } \\
\text { principles of self-regulation? }\end{array}$ & 48.5 & 23.4 & 28.1 & \\
\hline $\begin{array}{l}\text { Do you think that self-regulation could help you in your future } \\
\text { profession? }\end{array}$ & 40.6 & 22.9 & 36.5 & \\
\hline $\begin{array}{l}\text { Do you think that self-regulation techniques can help you to better } \\
\text { regulate own psychic and physical condition in everyday life? }\end{array}$ & 47.1 & 13.3 & 39.6 & \\
\hline
\end{tabular}

Effectiveness of our methodic is witnessed about by results of diagnostic of students' anxiety at control stage of research (see table 2). In experimental group we found no confident differences between anxiety indicators $(2.76 \%, \mathrm{p}<0.05)$; in control group anxiety indicator increased by $24.86 \%$, with high degree of confidence $(\mathrm{p}<0.001)$.

Table 2. Indicators of students' anxiety

\begin{tabular}{|c|c|c|c|c|c|}
\hline \multirow{2}{*}{ Group } & \multirow{2}{*}{$\begin{array}{l}\text { Stating stage } \\
\mathrm{M} \pm \mathrm{m}\end{array}$} & \multirow[t]{2}{*}{ Control stage } & \multicolumn{3}{|c|}{ Differences } \\
\hline & & & Absolute & $\%$ & $\mathbf{p}$ \\
\hline $\begin{array}{l}\text { Experimental } \\
\text { group }\end{array}$ & $33.49 \pm 0.76$ & $34.48 \pm 0.574$ & -0.99 & 2.76 & $>0.05$ \\
\hline $\begin{array}{l}\text { Control } \\
\text { group }\end{array}$ & $33.52 \pm 0.653$ & $42.29 \pm 1.217$ & -8.76 & 24.86 & $<0.001$ \\
\hline
\end{tabular}

Notes: $\mathrm{M}$ - mean arithmetic; $\mathrm{m}$ - mean error of mean arithmetic; $\mathrm{p}$-coefficient of confidence of differences.

Reduction of anxiety indicators in experimental group we explain by students' ability to consciously use self-regulation means. In control group anxiety indicator was higher. It can be connected with the fact that finish of training process and start of examination session create situations of increased intellectual and emotional overloads for students. With it not skilled in self-regulation students can not always resist such overloads. On control stage of experiment we conducted diagnostic of self-feeling of experimental and control groups' students before and after special course "Psycho-valueology". Comparative results are given in table 3. 
Table 2. Indicators of students' self-feeling

\begin{tabular}{|c|c|c|c|c|c|c|c|}
\hline \multirow{2}{*}{ Group } & \multirow{2}{*}{ Stages } & \multicolumn{2}{|c|}{$\begin{array}{l}\text { Self-feeling (points) } \\
M \pm m\end{array}$} & \multicolumn{4}{|c|}{ Differences } \\
\hline & & $\begin{array}{l}\text { Before } \\
\text { experiment }\end{array}$ & After experiment & Absolute & $\%$ & $\mathbf{t}$ & $\mathbf{p}$ \\
\hline \multirow{2}{*}{ Experimental } & Stating & $3.28 \pm 0.123$ & $3.36 \pm 0.114$ & 0.08 & 2.4 & 0.47 & $>0.05$ \\
\hline & Control & $3.96 \pm 0.108$ & $4.68 \pm 0.095$ & 0.72 & 18.2 & 5.00 & $<0.001$ \\
\hline \multirow{2}{*}{ Control } & Stating & $3.40 \pm 0.115$ & $3.68 \pm 0.125$ & 0.28 & 8.2 & 1.64 & $<0.05$ \\
\hline & Control & $3.76 \pm 0.133$ & $3.60 \pm 0.115$ & 0.16 & 44.3 & .0 .91 & $>0.05$ \\
\hline
\end{tabular}

Notes: $\mathrm{M}$ - mean arithmetic; $\mathrm{m}$ - mean error of mean arithmetic; $\mathrm{p}$-coefficient of confidence of differences.

After special course, indicators of experimental group students showed positive dynamic at control stage: improved by $17.3 \%(\mathrm{p}<0.001)$. Marks were in the range: "self-feeling is better than usually" and "good selffeeling". It confirms effectiveness of our methodic. In control group, self-feeling indicators improved only by $4.1 \%$. It also witnesses about effectiveness of our methodic. Thus, acquiring of self-regulation skills facilitated improvement of students' emotional and general condition.

Indicators of self-regulation culture's formation are ability to control own psycho-emotional state and conscious readiness to apply required means for this purpose. We determined indicators by self-assessment of theoretical knowledge formation, by students' practical and professional skills. They also were determined by experts' assessment of theoretical knowledge, practical and professional skills in application of self-regulation means. Comparative analysis is given in table 4.

Table 4. Students' readiness to apply self-regulation means (points)

\begin{tabular}{llllllll}
\hline Kinds of readiness & $\begin{array}{l}\text { Assessment } \\
\text { of readiness }\end{array}$ & $\begin{array}{l}\text { Stating stage } \\
\mathbf{M} \pm \mathbf{m}\end{array}$ & $\begin{array}{l}\text { Control } \\
\text { stage } \\
\mathbf{M} \pm \mathbf{m}\end{array}$ & Absolute & $\mathbf{\%}$ & $\mathbf{t}$ & $\mathbf{p}$ \\
\hline Theoretical & $\begin{array}{l}\text { Self- } \\
\text { assessment } \\
\text { Experts' } \\
\text { assessment }\end{array}$ & $1.30 \pm 0.093$ & $2.25 \pm 0.093$ & -0.95 & 70.0 & 6.73 & $<0.001$ \\
Self- & $1.45 \pm 0.09$ & $1.90 \pm 0.123$ & -0.46 & 30.1 & 2.78 & $<0.001$ \\
Practical & $\begin{array}{l}\text { Sssessment } \\
\text { Experts' }\end{array}$ & $1.41 \pm 0.097$ & $2.18 \pm 0.088$ & -0.77 & 52.1 & 5.39 & $<0.001$ \\
Professional & $\begin{array}{l}\text { assessment } \\
\text { Self- } \\
\text { assessment }\end{array}$ & $1.30 \pm 0.09$ & $2.13 \pm 0.100$ & -0.83 & 61.6 & 5.81 & $<0.001$ \\
\hline $\begin{array}{l}\text { Experts' } \\
\text { assessment }\end{array}$ & $1.33 \pm 0.09$ & $2.29 \pm 0.095$ & -0.95 & 68.0 & 6.73 & $<0.001$ \\
\hline
\end{tabular}

Notes: $\mathrm{M}$ - mean arithmetic; $\mathrm{m}$ - mean error of mean arithmetic; $\mathrm{p}$-coefficient of confidence of differences.

By criterion of theoretical readiness students' self-assessment increased by $70.0 \%$, experts' assessment increased by $40.8 \%$. By criterion of practical readiness (which characterizes students' ability to use self-regulation complex for stabilization of own psycho-emotional state) self assessment increased by $31.6 \%$. Experts' assessment increased by $52.1 \%$ that was higher than students' self assessment.

\section{Discussion}

Professional training of future physical culture teachers in modern conditions implies training of specialist, capable to fulfillment certain social role and his (her) readiness to form the culture of control of individual health in their disciples. It is that we call culture of self-regulation. In this important activity good results are not possible at the account of one or several methods' application [3, 11, and 16]. In process of health's formation and strengthening it is important to remember about complex character of the approach [15]. 
We completely support scientific approaches of specialists, who search pedagogic ways of health related technologies' implementation in educational system. The authors regard this process in wide cultural aspect [4, 14]. Our approach means that with determination of pedagogic conditions of health related technologies' implementation, accent shall be put on formation of students' conscious, value-oriented attitude to own health and health of surrounding people [13,14, and 15]. With such approach we create conditions for preservation and strengthening of rising generation's health as well as for possible solution of socially important problem overcoming of crisis of culture - by future generations.

\section{Conclusions:}

1. Training of future physical culture teacher envisages his (her) readiness to effectively fulfill professional functioning in health-related aspect. That is why formation of self-regulation culture is an integral component element of his (her) professional competence.

2. Formation of students' value-meaningful attitude to individual health and health of surrounding people are the necessary conditions of self-regulation culture's formation.

3. The conducted by us experimental research showed that implementation of special course "Psychovalueology" in practice of physical culture teachers' training gives positive health related effect.

\section{Acknowledgements:}

The research has been fulfilled as per topic of Chernigov National Pedagogical University, named after T.G. Shevchenko "Methodological principles of future physical culture teachers' professional training to culture of healthy life style formation in modern youth” (state registration №0110U000020 dt. January 29, 2010).

\section{Conflict of interests}

The author declares that there is no conflict of interests.

\section{References:}

1. Balakirieva OM, Bondar TV, Artiukh OR. Stan ta chinniki zdorov'ia ukrains'kikh pidlitkiv [Condition and factors of Ukrainian adolescents' health], Kiev: KIS; 2011. (in Ukrainian)

2. Bashavec' NA. Teoretiko-metodichni zasadi formuvannia kul'turi zdorov'iazberezhennia iak svitogliadnoi oriientacii studentiv vishchikh ekonomichnikh navchal'nikh zakladiv. Dokt. Diss. [Theoretical-methodic principles of formation of health protection culture as world vision orientation of higher economic educational establishments' students. Dokt. Diss.], Odessa; 2012. (in Ukrainian)

3. Golenkova IuV. Samoreguliaciia iak faktor formuvannia majbutnikh vchiteliv fizichnoi kul'turi. Cand. Diss. [Self-regulation as factor of formation of future physical culture teachers. Cand. Diss.], Kharkiv; 2011. (in Ukrainian)

4. Gorashchuk VP. Teoretichni i metodologichni zasadi formuvannia kul'turi zdorov'ia shkoliariv. Dokt. Diss. [Theoretical and methodological principles of formation of pupils' health culture. Dokt. Diss.], Kharkiv; 2004. (in Ukrainian)

5. Grin'ova MV. Teoretichni osnovi doslidzhennia zmistu samoreguliacii diial'nosti liudini [Theoretical principles of research of human self-regulation content]. Vitoki pedagogichnoi majsternosti, 2010;7:73-77. (in Ukrainian)

6. Dzhurins'kij PB. Teoretichni i metodichni zasadi pidgotovki majbutnikh uchiteliv fizichnoi kul'turi do zdorov'iazberezhuval'noi profesijnoi diial'nosti. Dokt. Diss. [Theoretical and methodic principles of future physical culture training to health protective professional functioning. Dokt. Diss.], Odessa; 2013. (in Ukrainian)

7. Iezhova OO. Zdorov'iazberigaiucha diial'nist' $v$ osvitnikh zakladakh [Health related functioning in educational establishments]. Osvitni innovacii, 2007;1:61-66. (in Ukrainian)

8. Kudin SF, Savonova OV. Dosvid roboti z formuvannia valeologichnogo svitogliadu majbutnikh pedagogiv [Practical experience in formation of valuelogic world vision of future pedagogues]. Visnik Chernigivs'kogo derzhavnogo pedagogichnogo universitetu, 2005;28:15-19. (in Ukrainian)

9. Kudin SF. Osnovi psikhovaleologii [Principles of psycho-valueology], Chernihiv: CSPU Publ.; 2005. (in Ukrainian)

10. Kuz'omko LM, Kudin SF, Savonova OV. Psikhovaleologiia [Psycho-valueology], Chernihiv: CSPU Publ.; 2007. (in Ukrainian) 
11. Lisenko-Gelemb'iuk KM. Samoreguliaciia iak chinnik rozv'iazuvannia mizhosobistisnikh konfliktiv students'koi molodi. Cand. Diss. [Self-regulation as factor of solution of students' inter-personal conflicts. Cand. Diss.], Kiev; 2011. (in Ukrainian)

12. Nosko MO, Bojko DO, Diatlov VO. Vishcha pedagogichna osvita i nauka Ukraini [Higher pedagogic education and science in Ukraine], Kiev: Knowledge of Ukraine; 2012. (in Ukrainian)

13. Nosko MO, Grishchenko SV, Nosko IuM. Formuvannia zdorovogo sposobu zhittia [Formation of healthy life style], Kiev: MP Lesya; 2013. (in Ukrainian)

14. Nosko MO, Iermakov SS, Garkusha SV. Teoretiko-metodichni aspekti zmicnennia fizichnogo zdorov'ia uchnivs'koi ta students'koi molodi [Theoretical-methodic aspects of strengthening of pupils' and students' physical health]. Visnik Chernigivs'kogo nacional'nogo pedagogichnogo universitetu, 2010;76:243-247. (in Ukrainian)

15. Nosko MO, Garkusha SV, Voiedilova OM. Zdorov'iazberezhuval'ni tekhnologii u fizichnomu vikhovanni [Health related technologies in physical education]. Kiev: SPD Savchinska N.V.; 2014. (in Ukrainian)

16. Titarenko EV. Professional'naia podgotovka budushchikh specialistov fizicheskoj kul'tury na osnove kompleksa sredstv psikhoreguliacii. Cand. Diss. [Professional training of future physical culture specialists on the base of complex of psycho-regulation means. Cand. Diss], Stavropol; 2006. (in Russian)

17. Iermakova TS. Education of children in Polish family in a context of forming health culture. Pedagogics, psychology, medical-biological problems of physical training and sports, 2014;11:17-22. http://dx.doi.org/10.15561/18189172.2014.1104

18. Iermakova TS. Development of the idea of forming health culture of a person in the world educational thought. Pedagogics, psychology, medical-biological problems of physical training and sports, 2014;4:8-12. http://dx.doi.org/10.6084/m9.figshare.950949

19. Iermakova TS. The peculiarities of work of the European network of health promoting schools (comparative analysis). Pedagogics, psychology, medical-biological problems of physical training and sports, 2013;10:9396. doi:10.6084/m9.figshare.775339

20. Ivashchenko OV, Yermakova TS. Assessment of functional, coordination and power fitness of 7-8 form boys. Pedagogics, psychology, medical-biological problems of physical training and sports. 2015;9:20-25. http://dx.doi.org/10.15561/18189172.2015.0903

21. Ivashchenko OV, Yermakova TS, Cieslicka M, Muszkieta R. Discriminant analysis as method of pedagogic control of 9-11 forms girls' functional and motor fitness. Journal of Physical Education and Sport, 2015;15(3):576-581.

22. Ivashchenko OV, Yermakova TS. Structural model of in-group dynamic of 6-10 years old boys' motor fitness. Pedagogics, psychology, medical-biological problems of physical training and sports, 2015;10:2432. http://dx.doi.org/10.15561/18189172.2015.1004

23. Yermakova TS. Individualization of forming health culture in schoolchildren of Polish schools. Pedagogics, psychology, medical-biological problems of physical training and sports, 2015;1:29-33. http://dx.doi.org/10.15561/18189172.2015.0106

24. Żukowska Hanna, Szark-Eckardt Mirosława, Muszkieta Radosław, Iermakova TS. Characteristics of body posture in the sagittal plane and fitness of first-form pupils from rural areas. Pedagogics, psychology, medical-biological problems of physical training and sports, 2014;7:50-60. http://dx.doi.org/10.6084/m9.figshare. 1015583 
Information about the author:

Kudin S.F.; htpp://orcid.org/0000-0002-9800-5525; kudyn@mail.ru; Chernigov National Pedagogical University; Getman Polubotka str. 53, Chernigov, 14013, Ukraine.

Cite this article as: Kudin S.F. Formation of self-regulation culture of physical education faculty. Physical education of students,

2016;1:49-54

doi:10.15561/20755279.2016.0107

The electronic version of this article is the complete one and can be found online at: http://www.sportpedu.org.ua/html/arhive-e.html

This is an Open Access article distributed under the terms of the Creative Commons Attribution License, which permits unrestricted use, distribution, and reproduction in any medium, provided the original work is properly cited (http://creativecommons.org/licenses/by/4.0/deed.en).

Received: 03.01.2016

Accepted: 12.01.2016; Published: 25.02.2016 